\title{
Eczema and atopy in early childhood: low IgA plasma cell counts in the jejunal mucosa
}

\author{
K S SLOPER, C G D BROOK, D KINGSTON, J R PEARSON, AND M SHINER \\ Department of Paediatrics, Central Middlesex Hospital, London, and Intestinal Studies Group, \\ Division of Clinical Sciences, Clinical Research Centre, Harrow
}

SUMMARY Twenty-one children aged between 2 and 54 months, 14 with eczema and 7 with allergies in first-degree relatives, were referred for diagnostic jejunal mucosal biopsy for a variety of symptoms. A partial villous atrophy was found in 19 of the 21 biopsies obtained; the other 2 were normal. We report a highly significant $(P<0.0001)$ lower IgA cell count in biopsies with partial villous atrophy compared with the results of our previous study of IgA and IgM plasma cells in the mucosal biopsies in children without eczema or a history of atopy matched for age and histological appearances. The IgM cell count was also lower.

Transient serum IgA deficiency is common in infants with eczema and in those with reaginic allergy in first-degree relatives. ${ }^{1}$ This may apply only to the first few months of life. ${ }^{2}$ IgA deficiency has also been incriminated as one of the factors leading to increased absorption of antigenic material through the gut in infancy. ${ }^{3}$ It is not yet clear whether this persists in allergic children. We therefore counted the jejunal mucosal IgA (and IgM) plasma cells of all infants and young children who had eczema or a history of atopy in first-degree relatives chosen from a wider group of patients referred to us for jejunal biopsy for a variety of symptoms. A previous study of mucosal IgA and IgM plasma cell counts ${ }^{4}$ in non-eczematous children served as a comparison. In that paper it was established that the IgA plasma cell count was greatly increased in partial villous atrophy (PVA) and subtotal villous atrophy, but apart from this, the type of disease did not correlate with cell counts. There was also some correlation of increase in plasma cell counts with increase in age. We therefore compared the counts from the current study with counts from the previous one in the same age and histological categories.

\section{Patients}

Among children referred for diagnostic jejunal biopsy because of diarrhoea, failure to thrive, iron deficiency, or vomiting we found 14 with eczema and 7 with allergies in first-degree relatives (Table 1). These 21 children are subsequently referred to as 'atopics' when compared with 'non-atopics' in our previous study. ${ }^{4}$ Of the 14 children with eczema, 10 also had other allergic manifestations, and there was a family history of atopy in 6 . Of the 7 children without eczema but with a family history of atopy, 4 also had other allergies. The diagnosis of food allergy (Table 1) is based on a history of symptoms after the introduction of the food. In some patients skin tests or oral challenges were carried out.

The clinical presentation of the patients from our previous study ${ }^{4}$ with whom comparisons are made is as follows. In the histologically normal category there were: failure to thrive $(n=5)$, cows' milk protein intolerance (cows' milk eliminated) $(n=3)$, chronic diarrhoea $(n=3)$, fibrocystic disease $(n=1)$. In the PVA category (see criteria below) there were: chronic diarrhoea $(n=6)$, cows' milk protein intolerance (on cows' milk, $n=4$ ) (cows' milk eliminated, $n=1)$, failure to thrive $(n=1)$, acute diarrhoea $(n=1)$, probable coeliac disease $(n=1)$, iron deficiency anaemia $(n=1)$. Patients with atopic manifestations were excluded from that study in which we concluded that the type of disease did not affect the IgA plasma cell counts. We therefore chose the patients for comparison by age and histological category only.

At the time of biopsy none of the patients was exclusively breast-fed; 13 had received breast milk for between 3 weeks and 10 months and 2 were still partly breast-fed. All patients had received cows' milk or modified cows' milk for the previous few weeks, except Case 9 whose biopsy was taken after a milk challenge. 
Table 1 Clinical data

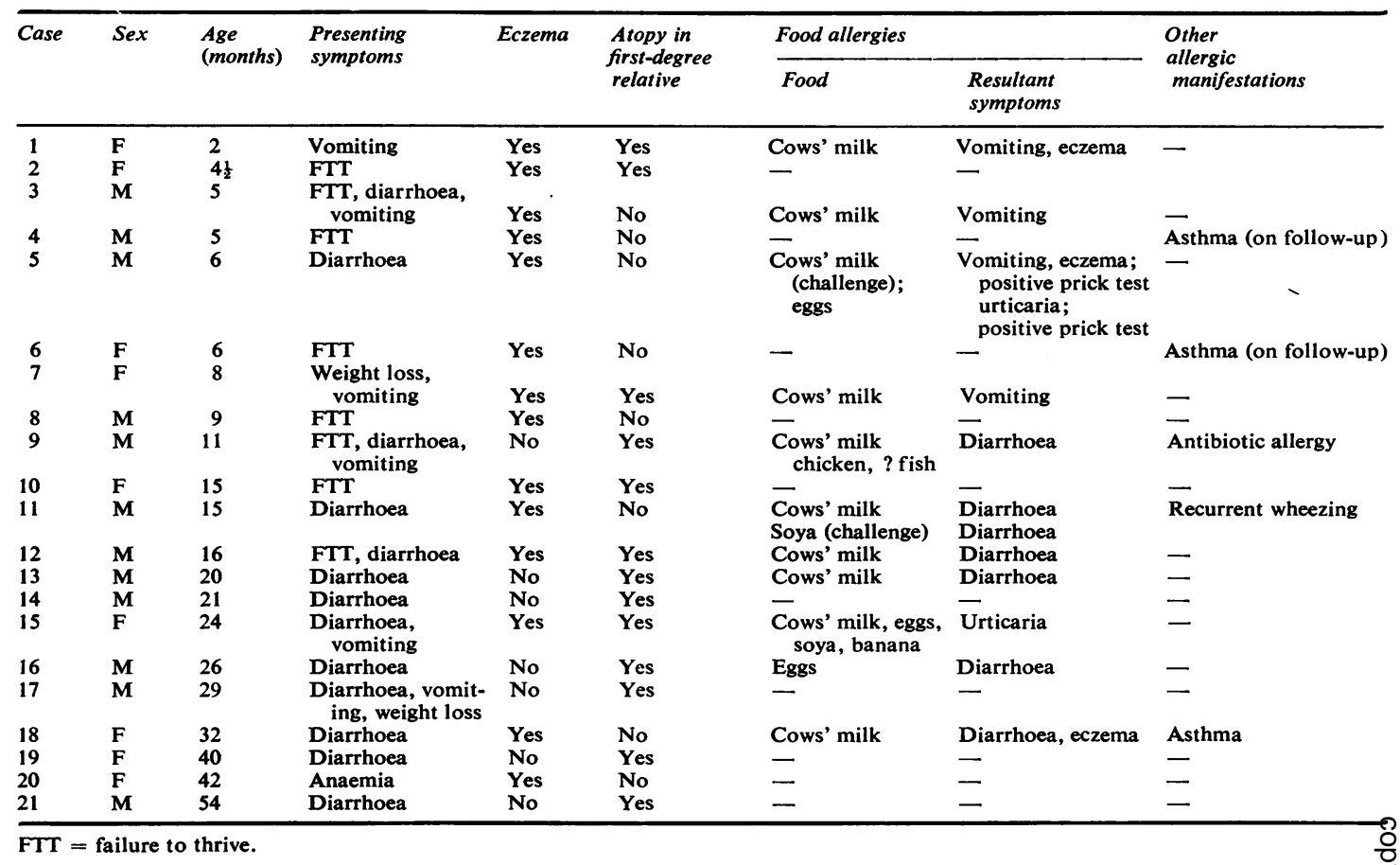

\section{Methods}

Jejunal biopsies at the ligament of Treitz were obtained with a paediatric Crosby capsule in all 21 patients. The mucosal specimens were divided into two, one portion for routine histology and the other for immunofluorescence as described. ${ }^{4}$ For immunofluorescence the tissue was immediately fixed in $5 \%$ formaldehyde for 4 hours, washed in a $30 \%$ sucrose solution, and stored at $-80^{\circ} \mathrm{C}$ until use. Sections, $6 \mu \mathrm{m}$ thick, were cut on a cryostat, treated with Dakopatts heavy-chain specific conjugates, and viewed with a Leitz orthoplan fluorescence microscope. The number of plasma cells stained with the fluorescent antisera was counted per mucosal unit, taking the mean of at least 15 units, which we have defined as a column $232 \mu \mathrm{m}$ wide, the baseline of which was the muscularis mucosae and reaching the tip of vertically cut villi.

The biopsies were classed histologically as normal or as showing PVA. ${ }^{5}$ In 14 of the 21 mucosa the haematoxylin and eosin ( $\mathrm{H}$ and $\mathrm{E})$ sections were well orientated and morphometry was carried out. Ten villi from each of these biopsies were measured from the villus-crypt junction to the villus tip using an eyepiece graticule calibrated with a micrometer slide and a Dynascope viewing head. On the basis of canonical analysis of previous morphometry ${ }^{6}$ the villus height was found to be the best single measurement to distinguish between normal and PVA, with PVA defined as a mean villus height of less than $285 \mu \mathrm{m}$ (Fig. 1). The orientation of the $\mathrm{H}$ and $\mathrm{E}$ sections from Cases 1, 2, 4, 6, 7, 10, and 18 was not considered adequate for morphometric purposes, and they were classified visually only. It was considered that the orientation of these 7 biopsies was adequate for visual assessment by an experienced histologist. The good relationship between visual and morphometric assessment found previously, ${ }^{6}$ was confirmed in this study.

\section{Results}

In all 12 patients tested, serum IgA, IgG, and IgM levels were normal; 5 out of 6 patients tested had a high serum IgE.

Histology. Of the 21 biopsies, 19 showed PVA and 2 were normal (Table 2). Of those biopsies measured morphometrically $(n=14)$ there was no difference between the distribution of villus heights in the present group with PVA and those non-atopic children in whom PVA studies had been done previously ${ }^{6}$ (Fig. 1). 
Mucosal plasma cell counts. IgA and IgM plasma cell counts in the mucosae of the 21 children (Table 2) were compared with counts of those previously

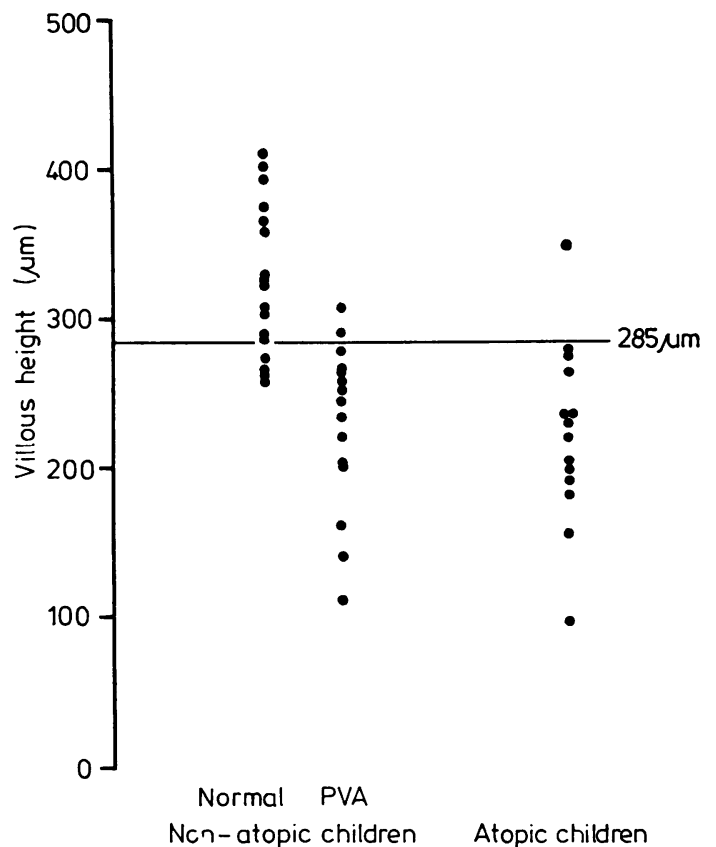

Fig. 1 Villus height distribution for non-atopic children $^{6}$ (aged 5-54 months) and atopic children (aged 2-54 months). A villus height of $285 \mu \mathrm{m}$ was chosen by canonical analysis as the point of division between biopsies classified subjectively as normal or partial atrophy $(P V A)$.

Table 2 Histological and immunofluorescence data

\begin{tabular}{|c|c|c|c|c|}
\hline \multirow[t]{2}{*}{ Case } & \multirow{2}{*}{$\begin{array}{l}\text { Villus } \\
\text { height } \\
(\mu \mathrm{m})\end{array}$} & \multirow{2}{*}{$\begin{array}{l}\text { Histological } \\
\text { category }\end{array}$} & \multicolumn{2}{|c|}{ Plasma cells per mucosal unit } \\
\hline & & & $\operatorname{IgA}$ & $\operatorname{Ig} M$ \\
\hline $\begin{array}{r}1 \\
2 \\
3 \\
4 \\
5 \\
6 \\
7 \\
8 \\
9 \\
10 \\
11 \\
12 \\
13 \\
14 \\
15 \\
16 \\
17 \\
18 \\
19 \\
20 \\
21\end{array}$ & $\begin{array}{l}\text { NM } \\
\text { NM } \\
233 \\
\text { NM } \\
95 \\
\text { NM } \\
\text { NM } \\
204 \\
153 \\
\text { NM } \\
197 \\
180 \\
262 \\
229 \\
233 \\
274 \\
348 \\
\text { NM } \\
219 \\
190 \\
272\end{array}$ & $\begin{array}{l}\text { PVA } \\
\text { PVA } \\
\text { PVA } \\
\text { PVA } \\
\text { PVA } \\
\text { PVA } \\
\text { PVA } \\
\text { PVA } \\
\text { PVA } \\
\text { PVA } \\
\text { PVA } \\
\text { PVA } \\
\text { PVA } \\
\text { PVA } \\
\text { PVA } \\
\text { PVA } \\
\text { Normal } \\
\text { Normal } \\
\text { PVA } \\
\text { PVA } \\
\text { PVA }\end{array}$ & $\begin{array}{l}32 \cdot 1 \\
42 \cdot 8 \\
46 \cdot 5 \\
47 \cdot 9 \\
48 \cdot 5 \\
87 \cdot 0 \\
22 \cdot 0 \\
29 \cdot 9 \\
77 \cdot 1 \\
54 \cdot 9 \\
35 \cdot 1 \\
27 \cdot 2 \\
39 \cdot 8 \\
37 \cdot 7 \\
22 \cdot 1 \\
71 \cdot 8 \\
28 \cdot 4 \\
37 \cdot 7 \\
38 \cdot 9 \\
69 \cdot 2 \\
53 \cdot 0\end{array}$ & $\begin{array}{r}8 \cdot 9 \\
12 \cdot 3 \\
8 \cdot 4 \\
9 \cdot 0 \\
23 \cdot 7 \\
6 \cdot 0 \\
15 \cdot 3 \\
17 \cdot 2 \\
18 \cdot 0 \\
16 \cdot 0 \\
4 \cdot 4 \\
20 \cdot 8 \\
12 \cdot 0 \\
12 \cdot 6 \\
3 \cdot 3 \\
5 \cdot 2 \\
2 \cdot 1 \\
6 \cdot 5 \\
5 \cdot 6 \\
6 \cdot 4 \\
6 \cdot 6\end{array}$ \\
\hline
\end{tabular}

PVA $=$ partial villous atrophy, $\mathrm{NM}=$ no morphometry. obtained in non-atopic children ${ }^{4}$ with similar age and histology. These had been found to be significantly higher $(P<0.001)$ in PVA than in normal mucosa. Fig. 2 shows that the IgA counts for atopic children with PVA were lower in each age group than for the non-atopic children with PVA. Taking all age groups together the difference was highly significant $(\mathbf{P}<0.0001)$. There was no difference in the distribution of IgA plasma cell counts in jejunal mucosae of patients according to whether they themselves had eczema or other atopies, or atopy in first-degree relatives.

In Fig. 3 IgM plasma cell counts for atopic children are compared with those for non-atopic children in relation to age and histology. There is no appreciable difference between the two groups,

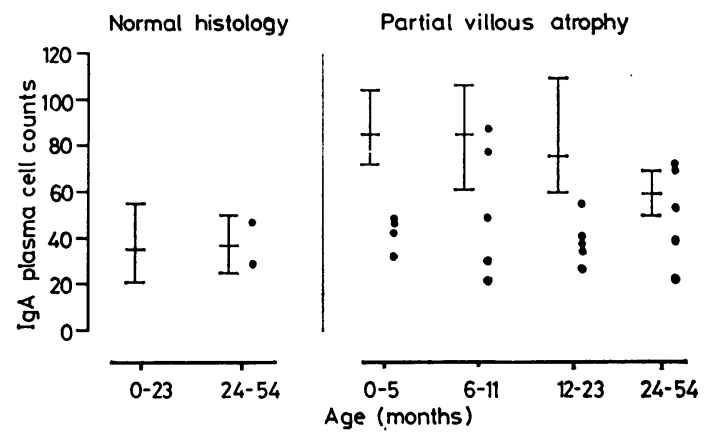

I Non-atopic children

I Mean and range

- Atopic children

Fig. 2 IgA plasma cell counts per mucosal unit. Twenty-one atopic children were compared with nonatopic children ${ }^{4}$ in the same age range and histological category.

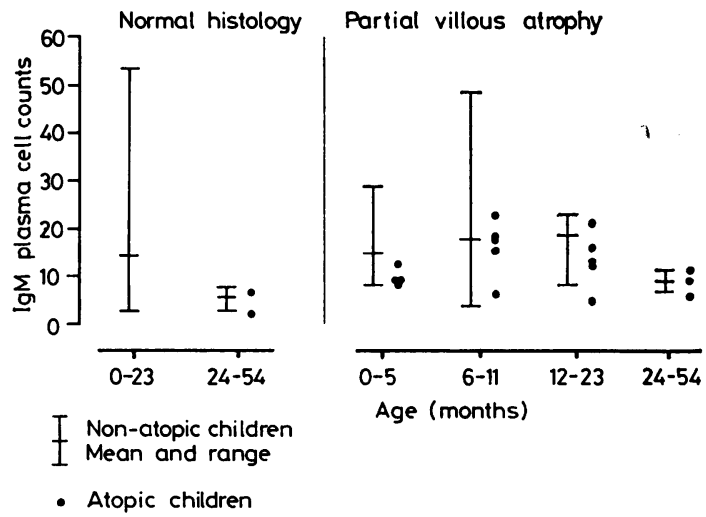

Fig. 3 IgM plasma cell counts per mucosal unit. Twenty-one atopic children were compared with non-atopic children ${ }^{4}$ in the same age range and histological category. 
although in PVA the IgM plasma cell counts tended to be lower in the atopic children.

\section{Discussion}

The neonatal gut is permeable to macromolecules and by this route the local and systemic immune system is stimulated. ${ }^{7}$ Antibody production is influenced by the amount and physical properties of the absorbed antigen, by intestinal permeability, and by stimulation of local plasma cells which appear as early as 12 days after birth. ${ }^{8}$ During the first month of life IgM plasma cells predominate with IgA plasma cells rising slowly thereafter. ${ }^{8}$ Although direct evidence is lacking, it was postulated on the basis of serum studies ${ }^{29}$ that in atopic infants and children this transient and physiological IgA deficiency might be prolonged. Such a state could adversely affect antigen exclusion in the gut and predispose to the development of eczema or other allergic manifestations in susceptible individuals. ${ }^{9}$ In two longitudinal studies of children who later developed atopic disease ${ }^{29}$ low serum IgA levels were indeed found at age 3 months. We now demonstrate a lower than expected IgA plasma cell count at the jejunal mucosal level in atopy.

In this study we: also show a high incidence of PVA - that is short villi, increase in crypt length, and inflammatory cells in the jejunal mucosa of children with eczema or allergy in first-degree relatives. Increased crypt length was also noted by Savilahti et al. ${ }^{10}$ in children with atopic eczema owing to food allergy. Our previous morphometric study of jejunal biopsies of 42 children $^{6}$ included only 1 atopic child. The 18 children free of gut symptoms (mainly with failure to thrive) and the 23 children with chronic diarrhoea had an incidence of PVA of $37 \%$ and $48 \%$ respectively. The incidence of $90 \%$ PVA in this present group of 21 atopic children is thus very striking. Because of the importance of the histological classification in establishing the reduction in IgA counts it was confirmed by villus height measurements.

In a previous paper ${ }^{4}$ it was observed that children with PVA had a significantly higher number of IgA plasma cells than those, matched for age, with normal histology, indicating that histological abnormalities correlate with an increased immune response, with $\operatorname{IgA}$ as the major immunoglobulin. As there was in that study no correlation with the type of gastrointestinal disease, a possible explanation was that the gut in PVA was abrormally permeable to antigen and the increased $\operatorname{IgA}$ count was in response to this. Our present findings that IgA plasma cell counts in atopic children with PVA are lower than those in non-atopic children with PVA suggests that, with the same histological abnormality, the local o? immune response in atopics is less efficient than in $\ddot{\vec{F}}$ non-atopics. IgA plasma cell count associated with $\stackrel{\vec{D}}{\vec{D}}$ PVA was low at all ages. The normal-to-low IgM plasma cell counts in this study differs from reports of a compensatory rise in IgM cells in the presence of low IgA cell counts. ${ }^{11}$ It suggests depression of the local immune response of both IgA and IgM type; this pattern was also suggested for serum immunoglobulins in atopic patients. ${ }^{12}$

We thank Dr I D Hill, Division of Computing and Statistics, Clinical Research Centre, for calculating probabilities.

\section{References}

1 Soothill J F, Stokes C R, Turner M W, Norman A P, Taylor B. Predisposing factors and the development of reaginic allergy in infancy. Clin Allergy 1976; 6: 305-19.

2 Orgel H A, Hamburger $\mathbf{R}$ N, Bazaral M, Gorrin $H$, Groshong T, Lenoir M, Miller J R, Wallace W. Development of IgE and allergy in infancy. $J$ Allergy Clin Immunol 1975; 56: 296-307.

3 Walker W A. Antigen absorption from the small intestine and gastrointestinal disease. Pediatr Clin North Am 1975; 22: 731-46.

4 Maffei H V L, Kingston D, Hill I D, Shiner M. Histopathologic changes and the immune response within the jejunal mucosa in infants and children. Pediatr Res 197 13: 733-6.

${ }^{5}$ Doniach I, Shiner M. Duodenal and jejunal biopsies II. Histology. Gastroenterology 1957; 33: 71-86.

- Penna F J, Hill I D, Kingston D, Robertson K, Slavin G, Shiner M. Jejunal mucosal morphometry in children with and without gut symptoms and in normal adults. $J$ Clin Pathol 1981; 34: 386-92.

7 Walker W A, Isselbacher K J. Uptake and transport of macromolecules by the intestine: possible role in clinical disorders. Gastroenterology 1974; 67: 531-50.

8 Perkkiö M, Savilahti E. Time of appearance of immunoglobulin-containing cells in the mucosa of the neonatal intestine (abstract). Acta Paediatr Belg 1979; 32: 226.

- Taylor B, Norman A P, Orgel $\mathbf{H}$ A, Turner M W, き Stokes C R, Soothill J F. Transient IgA deficiency and ? pathogenesis of infantile atopy. Lancet 1973; ii: 111-3.

10 Savilahti E, Backman A, Kuitunen P, McCalla R, 3 Perkkiö M. Morphological and immunohistochemical study of jejunal biopsies from children with atopic eczema due to food allergy (abstract). Acta Paediatr Belg 1979; 32: 226.

11 Savilahti E. IgA deficiency in children. Immunoglobulincontaining cells in the intestinal mucosa, immunoglobulins in secretions, and serum IgA levels. Clin Exp Immunol 1973; 13: 395-406.

12 Kaufman H S, Hobbs J R. Immunoglobulin deficiencies o in an atopic population. Lancet 1970; ii: 1061-3.

Correspondence to Dr C G D Brook, Central Middlesex Hospital, Department of Paediatrics, Acton Lane, London NW10 7NS.

Received 15 December 1980 